\title{
Status of Serbian Towns in the Light of Recent Efforts Towards a National Decentralisation Strategy
}

\author{
Bogoljub Milosarljevic \\ Jelena Jerimic**
}

UDK

352.071(497.11)

35.072.1(497.11)

35.071.55(497.11)

Review scientific paper / pregledni znanstveni rad

Received/primljeno: 30.6. 2015.

Accepted/prihvaćeno: 1. 4. 2016.

Decentralisation has been recognised as one of the key priorities of the 2014 Serbian Public Administration Reform Strategy. To that end, the Serbian Government has taken steps towards preparing a national decentralisation strategy. Serbia has a single-level and almost completely monotype structure of local government, in which towns have the same organisation of bodies, and almost identical competences as municipalities do, including some minimal exceptions for the Town of Belgrade, as the country's capital. In the light of the ongoing discussions on decentralisa-

* Bogoljub Milosavljević, full professor, Faculty of Law, Union University, Belgrade, Serbia (profesor Pravnog fakulteta Sveučilišta Union, Beograd, Srbija, e-mail: bogoljub.milosavljevic@pravnifakultet.rs)

** Jelena Jerinić, assistant professor, Faculty of Law, Union University, Belgrade, Serbia (docentica Pravnog fakulteta Sveučilišta Union, Beograd, Srbija, e-mail: jelena.jerinic@ pravnifakultet.rs) 
tion in general and, more specifically, on the reform of the local government system, the authors comment on some of the issues in the centre of that discussion, particularly those relating to the status of towns in general and the status of the capital, and provide proposals for possible overall reforms of the local government system. Consequently, these issues will be analysed from the perspective of the need to alter the current constitutional framework.

Keywords: decentralisation, strategy, local self-government, local government, town, mayor, Serbia

\section{Introduction}

At the beginning of 2014, the Serbian Government adopted its second Public Administration Reform Strategy (PARS, Official Gazette of the Republic of Serbia, OGRS 9/14, 42/14). The first strategy was realised during the period 2004-2013 with limited positive effects, mainly in the normative sphere, and a much more modest performance in the reform of ineadequate practices (OECD-Sigma, 2013).

Among its other objectives, the current strategic document declares a need to draft and adopt a National Decentralisation Strategy. The Government ascertained that the aim of decentralisation should not be to merely disempower central authorities and transfer competences to nonstate actors, but that the process would make sense only if it enabled quality public service which would meet citizens' everyday needs, wherein these needs are best recognised by the authorities closest to the citizens.

By the end of 2014, two important documents were produced towards preparation of the National Decentralisation Strategy: (1) a situation analysis of the local self-government system in Serbia, and (2) a study of two possible decentralisation models - one within the boundaries of the current constitutional framework, and the other presupposing certain constitutional changes. ${ }^{1}$ The third step of the preparatory process, envisaged for the first half of 2015, was a cost-benefit analysis of both

1 The first document was drafted by a group of authors for the Standing Conference of Towns and Municipalities (SCTM), the national local government association, which took an active part in the discussions on the planned decentralisation strategy. The latter was solicited by the OSCE Mission to Serbia, in order to assist the Serbian Ministry of Public 
decentralisation models. That particular analysis is not the subject of this paper. Afterwards, the results of the analyses would be presented to competent national bodies which would initiate the drafting of the National Decentralisation Strategy.

A reassessment of the status of towns represents one of the key points in this process. This paper presents and comments on some of the main ideas regarding possible and desired changes to their status. The authors share the belief that sources of ideas on how to resolve issues of decentralisation in general, including the case of towns, should be sought both in purely theoretical considerations and comparative law, as well as in one's own legal heritage. Starting from that premise, the paper first presents the basic features of the status of towns in the present local self-government system in Serbia, which are well known in Serbian legal literature, but probably less so in literature written in English and published outside of Serbia. This is followed by a very brief section on comparative experiences and a somewhat more detailed presentation of Serbian local government history. In the final part, the paper presents the elements of the two formulated decentralisation models, including the proposed future status of towns.

\section{Basic Features of the Present System of Local Self-Government}

Serbia has a single-level local self-government system, with municipalities (opštine), towns (gradovi) and the Town of Belgrade (grad Beograd) as its units (Vasiljević, 2008). There is a total of 174 local self-government units: 150 municipalities, 23 towns and the Town of Belgrade. Until 2007, legislation on territorial organisation envisaged only five towns. ${ }^{2}$ That was the year another 19 big municipalities gained town status. ${ }^{3}$ The Law on Territorial Organisation of the Republic of Serbia (OGRS 129/07) now defines a town as an economic, administrative, geographical and cultural centre

Administration and Local Self-Government. In both cases, the authors of this article were engaged as experts.

2 Belgrade, Novi Sad, Priština, Kragujevac, and Niš.

${ }^{3}$ Valjevo, Vranje, Zaječar, Zrenjanin, Jagodina, Kraljevo, Kruševac, Leskovac, Loznica, Novi Pazar, Pančevo, Požarevac, Smederevo, Sombor, Sremska Mitrovica, Subotica, Užice, Čačak, and Šabac. 
of a wider area, with a population of over 100,000 inhabitants - with the exception that a territorial unit with fewer than 100,000 inhabitants may be defined as a town in the case of specific economic, geographic or historical reasons. This exception was widely applied, so presently there are as many as nine towns (out of the total 24) with fewer than 100,000 inhabitants (Table 1). Similar to a municipality, the territory for which a town is established has to form a natural geographic entirety, an economically connected area with developed communication between its settlements, and a seat as its gravitation centre. Besides by the number of inhabitants, current towns differ significantly by the size of their territory and the number of settlements (Table 1).

The legal definition of town as a local self-government unit differs from the concept of town in its usual linguistic and everyday sense. In this sense a town is an urban-type settlement, while a town as a local self-government unit includes not only urban settlements, but also their wider surroundings, i.e. all the settlements in a wider area, while some of these (one or more) may have the character of an urban settlement and others may be of suburban character (Petovar, 2007; Stevanović, 2004: 110-111; Stojkov, 2007). In practical terms, the only change brought about by the 2007 law was that areas of several former municipalities, which had had a certain number of inhabitants, were declared towns. The difference between an urban settlement and a town as a local self-government unit indicated here is obvious from the fact that there are 193 urban settlements in Serbia, and only 24 towns. On the territory of the Town of Belgrade, for instance, there are 16 urban settlements; i.e. Belgrade and 15 smaller towns (Table 1).

Towns can establish so-called town municipalities (gradske opštine) which do not have the legal status of local self-government units; i.e. they do not have their own self-government competences, but perform some tasks conferred on them by towns from the circle of their own competences. Currently, these exist in six towns and there are 30 of them in total. ${ }^{4}$ The establishment of town municipalities is within the domain of towns and is regulated by their statutes. If a town does choose to establish town municipalities, its only obligation is to establish at least two of them. The Law on the Capital (OGRS 129/07) presents an exception in that respect, determining that Belgrade is obliged to establish town municipalities, while their number, establishment or abolition is determined by Belgrade's stat-

${ }^{4} 17$ in Belgrade, five in Niš, and two each in Novi Sad, Vranje, Požarevac, and Užice. 
ute. Although all town municipalities formally have a more or less equal legal status, differences between them in individual towns concern the circle of public tasks delegated to them from the towns' competences, as well as some elements of their organisation, relations to town authorities, financing etc. In our view, those differences are a logical consequence of the different needs of specific towns and their right to regulate towards meeting those needs, but on the other hand this has resulted in an absence of any kind of regulation of the status of town municipalities in national legislation.

The territory of municipalities and towns can be divided into so-called local communities or neighbourhood units (mesne zajednice). ${ }^{5}$ On the territory of central Serbia and the Autonomous Province of Vojvodina there is a total of 4,121 of these (Table 1). As town municipalities, they are not local self-government units.

Table 1: Data on territory, number of town municipalities, settlements and neighbourbood units, and population in towns

\begin{tabular}{|l|r|r|r|r|r|}
\hline Towns & $\begin{array}{c}\text { Territory } \\
\left(\mathrm{km}^{3}\right)\end{array}$ & $\begin{array}{c}\text { Number of } \\
\text { town munic- } \\
\text { ipalities }\end{array}$ & $\begin{array}{c}\text { Number of } \\
\text { settlements }\end{array}$ & $\begin{array}{c}\text { Number of } \\
\text { neighbour- } \\
\text { hood units }\end{array}$ & $\begin{array}{c}\text { Population } \\
\text { in 2013 }\end{array}$ \\
\hline Belgrade & 3,234 & 17 & 157 & 267 & $1,669,552$ \\
\hline Novi Sad & 699 & 2 & 16 & 46 & 346,163 \\
\hline Niš & 596 & 5 & 71 & 17 & 259,125 \\
\hline Kragujevac & 835 & & 57 & 78 & 179,030 \\
\hline Leskovac & 1,025 & & 144 & 139 & 141,719 \\
\hline Subotica & 1,007 & & 19 & 37 & 140,233 \\
\hline Kruševac & 854 & & 101 & 55 & 126,900 \\
\hline Kraljevo & 1,530 & & 92 & 68 & 123,724 \\
\hline Pančevo & 756 & & 10 & 17 & 122,492 \\
\hline Zrenjanin & 1,327 & & 22 & 36 & 121,683 \\
\hline Šabac & 797 & & 52 & 61 & 114,548 \\
\hline Čačak & 636 & & 58 & 69 & 114,141 \\
\hline Smederevo & 484 & & 28 & 38 & 107,048 \\
\hline
\end{tabular}

${ }^{5}$ So far, the authors have not come across an adequate translation of the Serbian term mesne zajednice. In some sources, the term "sub-administrative administrative units" is used, but it is not used here, as it may lead to the conclusion that these are units of deconcentration, which is not the case. In the remainder of this text the term "neighbourhood units" is used since, in the authors' opinion, it best depicts the essence of this institute. 


\begin{tabular}{|l|r|r|r|r|r|}
\hline Novi Pazar & 742 & & 99 & 26 & 102,122 \\
\hline Valjevo & 905 & & 78 & 50 & 89,112 \\
\hline Sombor & 1,216 & & 16 & 22 & 84,187 \\
\hline Vranje & 860 & 2 & 105 & 52 & 82,845 \\
\hline Sr. Mitrovica & 762 & & 26 & 34 & 78,776 \\
\hline Loznica & 612 & & 54 & 56 & 78,136 \\
\hline Užice & 667 & 2 & 41 & 30 & 76,886 \\
\hline Požarevac & 477 & 2 & 27 & 38 & 74,713 \\
\hline Jagodina & 470 & & 53 & 60 & 71,583 \\
\hline Zaječar & 1,069 & & 34 & 35 & 58,183 \\
\hline
\end{tabular}

Source: Serbian Statistical Office

Above the level of municipalities and towns the territorial organisation of Serbia also comprises two autonomous provinces as territorial autonomy units (Milosavljević, 2012b). Finally, there are administrative districts (upravni okruzi), established for the territory of several municipalities and towns, with the exception of the Town of Belgrade (since the seats of central state bodies are situated there). There are 29 administrative districts and they are a form of deconcentration, not decentralisation. ${ }^{6}$ The 2009 Law on Regional Development (LRD, OGRS 51/09, 30/10) established five regions as statistical functional territorial units (referred to here as developmental districts). They correspond to NUTS 2 units and consist of one or more districts (oblasti) corresponding to the NUTS 3 level. The territory of the 30 developmental districts corresponds mainly to the division into administrative districts, with the addition of Belgrade. Belgrade is thus considered both a district and a developmental region in the meaning of the LRD. Developmental regions are not local or regional self-government units as they do not have their own elected bodies or competences, nor are they administrative units of deconcentration, but exist for purely statistical purposes and those of realising the national regional development strategy (Jerinić, 2012). Table 2 depicts the division of Serbia into developmental regions in terms of their concurrence with other existing territorial units.

${ }^{6}$ These 29 districts were first introduced by government decree in 1991. In 2005 they were named administrative districts (upravni okruzi) by the Law on State Administration (OGRS 79/05, 101/07, 95/10, 99/14) with a somewhat wider legal framework. Following the 2005 Law, the same administrative districts were established by the Government Decree on Administrative Districts (Uredba o upravnim okruzima, OGRS 15/06). 
Table 2: Administrative division of the Republic of Serbia in compliance with the NUTS classification

\begin{tabular}{|c|c|c|c|c|c|c|}
\hline Regions (NUTS 2) & 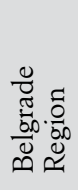 & 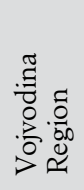 & 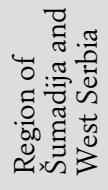 & 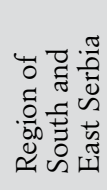 & 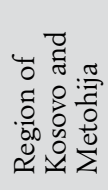 & $\stackrel{\pi}{\stackrel{\pi}{0}}$ \\
\hline Districts (NUTS 3) & 1 & 7 & 8 & 9 & 5 & 30 \\
\hline Administrative districts & 0 & 7 & 8 & 9 & 5 & 29 \\
\hline Town of Belgrade & 1 & & & & & 1 \\
\hline Towns in total & 1 & 6 & 10 & 6 & 1 & 24 \\
\hline Municipalities & 0 & 39 & 42 & 41 & 28 & 150 \\
\hline $\begin{array}{l}\text { Local self-government } \\
\text { units in total }\end{array}$ & 1 & 45 & 52 & 47 & 29 & 174 \\
\hline Settlements in total & 157 & 467 & 2,112 & 1,973 & 1,449 & 6,158 \\
\hline Urban settlements & 16 & 52 & 53 & 46 & 26 & 193 \\
\hline
\end{tabular}

Source: Serbian Statistical Office

All towns with the exception of Belgrade have the same status. The specific status of Belgrade is recognised by the Constitution, envisaging that a special law is to be passed regarding its status and that it can have wider competences (additional tasks) than other towns (Art 189/5). However, relevant legislation introduced only minimal differences in competences between other towns and the Town of Belgrade, as well as between all towns and municipalities. More specifically, all towns and municipalities have bodies of the same type, differing only in the number of deputies in their assemblies and members of executive bodies (town or municipal council, opštinsko/gradsko veće), and to some extent in the organisation of their administrations (a single local administration or several local administrations established for different fields of competence). Therefore the local self-government system is basically monotype, since it rests on a uniform model for all towns and municipalities, regardless of their type, size, population and other differences (Milosavljević, 2009: 17-18; Milosavljević, 2012a: 752-754). The authors hold that this monotype setting of the local government system causes numerous deficiencies in the way that it functions, some of which are outlined in the remaining text. The most obvious problem caused by such a setting is that it prevents lo- 
cal governments with greater capacities to take on greater responsibilities, while at the same time those with lower capacities sometimes fail to fulfill even the basic tasks.

Within town (as well as municipal) competences we can distinguish between their original (self-government) tasks and delegated tasks. The original competences encompass a relatively long list of tasks belonging to different fields. ${ }^{7}$ However, the majority of these competences are incomplete or overly conditional upon formal limitations introduced by legislation (Milosavljević, Jerinić, 2012: 10-17). So far towns have had an additional competence in establishing their own local (communal) police, and the Town of Belgrade has three additional original competences. ${ }^{8}$

The circle of delegated competences is wide and encompasses significant tasks, with a general approach that the same tasks are delegated to all municipalities and towns (a linear approach). Only on a few occasions were the tasks delegated only to towns or to the Town of Belgrade. A comparison shows that there are fields in which significant tasks were delegated, as well as others in which this was not the case, even though both groups of tasks are similar in nature. ${ }^{9}$

In managing local public tasks a dominant role is given to their representative bodies, while direct citizen participation is underdeveloped (Vukelić, 2005; Mojsilović et al, 2011). The local assembly as the highest representative body elects two executive bodies: the mayor and the town council (in municipalities - a municipality president and a municipal council). The election of deputies to local assembly is based on the proportional electoral system and the town (or municipality) makes up a single electoral unit (Law on Local Elections - OGRS 129/07, 34/2010, 54/2011) (Vuković, 2015). The current local electoral system is not suitable for the local level and actually alienates citizens from elected deputies, since they are primarily responsible to their political parties.

7 Besides determining their own organisation, passing a statute, annual budgets, development plans and other important documents, the realm of original competences is dominated by those from the fields of communal services, construction land and office space leasing, maintenance of local roads and infrastructure of local importance, as well as certain tasks in the fields of education, culture, healthcare, social services and child care, tourism, crafts, catering, and trade.

${ }^{8}$ In the fields of waterpower engineering, roads, and fire protection.

9 Parallel to preparations for the decentralisation strategy, the Government undertook to establish a complete inventory of public tasks performed on all levels of government, since this did not exist for a few decades. 
The Law on Local Self-Government (OGRS 129/07, 83/2014) provides for a relatively large number of possible deputies (from 19 to 75 , and up to 110 for the Town of Belgrade), within which local statutes specify the exact number of deputies, thus enabling local governments of different sizes to all determine a number of deputies close to the maximum number. The total number of deputies in 145 municipalities and towns on the territory of central Serbia and the province of Vojvodina amounts to 6,612 (including deputies in town municipalities). A very simple change in legislation, determining an exact criterion for the determination of the number of deputies, e.g. based on the number of inhabitants or size of territory, would suffice.

A local assembly has a president, who can be permanently employed in the local government, as well as a deputy president and a secretary. Local assemblies annually hold six to ten sessions on average, while the number of sessions of assembly working bodies is higher. The operation costs of local assemblies are high and represent one of the highest expenses of local budgets, mainly caused by an upward trend of converging the deputies' engagement into some kind of a paid post..$^{10}$ The authors believe that this aspect is also, like the characteristics of the local electoral system, a result of the over-politicisation of society and visible influences of political parties on every aspect of society.

The relations between the two executive bodies are, in the functional sense, principally differentiated, but not in personal and factual terms, nor in terms of their responsibility and relations towards the local administration. Besides the municipality president and his/her deputy, i.e. the mayor and his/her deputy, municipal or town councils have 11 members elected by the assembly (there can be up to 13 members in the Town of Belgrade). Most of these are employed by the local government. The maximum number of all municipal and town council members would be 1,587 and the actual number is very close to that. Additionally, municipality presidents can have up to three, and mayors up to five assistants. If these are included, it follows that in 23 towns and 122 municipalities the local executive stratum encompasses around 2,400 people. ${ }^{11}$

In the elaboration of decentralisation models, the authors specifically raise the question of the necessity of having two executive bodies, and

10 Data presented here are the result of the authors' research conducted during 2014, s.n. 1 .

11 Ibid. 
further elaborate their proposals for the establishment of a single local executive body.

Regarding municipalities with up to 50,000 inhabitants, the Law on Local Self-Government determines that their administration is established as a single body, and in those which have more inhabitants, as well as in towns, there can either be a single administration or two or more administrations for specific fields (Milosavljević et al., 2012: 25-30). Towns have utilised this possibility in different ways and some have even established more than ten administrations. ${ }^{12}$ We cannot find any tangible criterion for the establishment of a concrete number of such administrations in specific local governments, which leads to the conclusion that such criteria are needed, perhaps even to be established by national legislation, as outlined in the models below.

The administrative capacities of local governments are unequal. The majority of towns have adequate capacities for the performance of all their tasks, while this is not the case in the majority of municipalities. On the contrary, the majority of towns and municipalities, similar to state administration, have a surplus of permanently or temporarily employed staff. According to an official estimate, the number of employees in the administration of 145 municipalities and towns amounts to a total of 45,042. ${ }^{13}$

Besides the main local bodies, a significant number of towns as well as municipalities have other bodies or offices, such as a council for interethnic relations, an ombudsperson, a public attorney's office, an office for legal aid, an office for the affairs of local communities (mesne zajednice), a mayor's office, staff for emergencies, local public agencies and public funds, one or more public utility companies, cultural institutions, public information institutions, social work centres, some social care institutions and a range of other municipal or town organisations (e.g. sports associations, the Red Cross, veterans' organisations, and tourist and other organisations). Except where the law clearly determines the method of their establishment, the status and role of the listed bodies or organisations,

12 Novi Sad has 15 separate administrations (administrative bodies), Leskovac and Niš have 11 administrations each, while Jagodina, Čačak, and Sremska Mitrovica have 8 each. On the other hand, Belgrade has a single administration.

13 Data of the Ministry of Finance for the territory of central Serbia and the Autonomous Province of Vojvodina on July 15, 2015, http://www.mfin.gov.rs/UserFiles/File/Registri\%20zaposlenih/2015/IzvestajBrojLokalzamaj2015.pdf. This number also includes local officials; i.e. all persons employed in municipalities and towns, as well as employees of other local public services and institutions funded from local budgets. The 145 municipalities include those on the territory of central Serbia and Vojvodina. 
their organisation, status, and financing is determined according to very heterogeneous models.

Despite the evident need for inter-municipal cooperation by way of establishing mutual bodies, offices, or public utility companies, it is present in limited, almost negligible volume (Pavlović-Križanić, 2010). Inter-municipal cooperation is founded on the principle of voluntarity and usually occurs when there are external incentives, such as possibilities of foreign donor funds, and far less often in the independent foresight of mutual interest and the need for a more rational and efficient performance of public tasks. Exceptions so far have included some cases of concessions, as well as other similar arrangements aiming at the establishment of public-private partnerships.

Local economic development as an important local government function has been properly recognised only in the past few years (Vasiljević, 2012). Consequently, capacities of individual local governments to perform this function differ greatly from the initial results, and are often unsatisfactory. Public utility companies have not yet been reformed. The design of a coherent regional development policy is also still in the initial phases, as well as the creation of the institutional capacities required for its realisation. Fiscal equalisation measures are undertaken by the central state within its budgetary policy, and on the basis of classification of local governments according to the level of their development. ${ }^{14}$ It aims at securing a minimal level of capacity for underdeveloped local governments to perform their functions, and is at the same time limited by a budgetary crisis. Due to all this, the capacity of local governments to provide an adequate level of public service differs and is often highly dependent on the assistance of the state budget.

The local government finance system established by the 2006 Law on Local Government Financing (OGRS 62/06, 47/11, 93/12) has not been

14 By government decree all local government units are classified in four groups according to the level of their development: the 1st group - 20 local governments with a development level above the national average, the 2nd group - 34 units with a level of development between 80 and 100 per cent of the national average, the 3rd group - 47 underdeveloped local government units with a level of development between 60 and 80 per cent of the national average and the 4 th group - 44 extremely underdeveloped units with a level of development under 60 per cent of the national average. Within the last group there are 19 local government units with a level of development under 50 per cent of the national average, which were granted the status of a devastated area. (Decree on the establishment of a uniform list of the development of regions and local self-government units for 2014, Uredba o utvrdivanju jedinstvene liste razvijenosti regiona i jedinica lokalne samouprave za 2014., OGRS 104/14). 
stable for several years now, also due to a serious fiscal and economic crisis. The relative importance of local finances in total public finances is lower than in European Union countries, but the total volume of local finances for current domestic circumstances is objectively high. ${ }^{15}$

Besides a frequent indication of the need for a more comprehensive financial oversight of local governments by the state, the analyses of national experts, as well as recommendations of experts of the Council of Europe, point towards certain shortcomings in the complete oversight system; primarily to the fact that state oversight is almost exclusively conceived as ex post oversight. Such oversight, by way of its very nature, cannot prevent the occurrence of illegal behaviour, but is only directed towards the detection of illegalities and other irregularities, and their sanctioning. The same applies to inspection oversight, which does not always have a preventive or advisory character. Nor are line ministries always ready to provide the necessary advice and solicited opinions on the application of legislation, often leaving local officials and civil servants to themselves, even when they show a readiness to prevent their own mistakes (Milosavljević, Nikolić, 2014).

\section{Main Sources of Ideas for Proposed Models of Decentralisation}

Every country in Europe has adopted its own model of territorial decentralisation, shaped by its tradition and specific characteristics of the social, political, and administrative system. That is the case with all subnational levels of government and particularly with local self-government. Despite

15 From the three types of public revenues of local budgets (original revenues, shared revenues and transfers), the most important revenues in 2013 were shared revenues (54.8\%), followed by original revenues $(26.4 \%)$, and transfers $(17.7 \%)$. The share of each of these revenue categories differs in individual municipalities and towns, so that there is an average share of transfers in 30 local governments, while in 36 of them these revenues comprise from 20 to 30 per cent of total revenues, in 47 over per cent, and in two municipalities as much as over 80 per cent. In the remaining 32 local governments the share of transfers is smaller than the average, and it is the smallest in Belgrade (0.5\%) and Novi Sad (6\%). The relationship between capital and current expenses in 2013 is such that capital revenues on average make up only $15.5 \%$ of the total expenses (the rest being current expenses). Within the category of current expenses, the dominant part belongs to expenses for employees and expenses for goods and services. Data presented here are the result of the research conducted during 2014 by Milica Bisić who was a member of the research team, s.n. 1. 
the wide acceptance of the European Charter of Local Self-Government, which sets only minimal common standards and guarantees of local selfgovernment, significant differences remain between local self-government systems, even among member states of the European Union. These differences relate both to the number and size of local government units, as well as to the organisation of local bodies, competences, financing and resources, oversight of local government operations, and legal protection of local self-government. In terms of middle or regional levels of government the situation is even more diverse. This is also described by the fact that despite numerous initiatives, a common binding document on regional self-government has not yet been adopted under the auspices of the Council of Europe, but only a reference framework for regional democracy. ${ }^{16}$ Since it does not have the character of a convention, this document was not offered for signature and ratification by the member states.

Moreover, local government systems in Europe have been subject to many reforms. During the last ten or fifteen years most of the examined countries have seen significant changes to the territorial organisation and essential features of their local government systems (e.g. Croatia, Denmark, Greece, and Romania) (CEMR, 2013).

Bearing that in mind, the two proposed models have taken into account only basic remarks on the characteristics of local and regional self-government systems, primarily in European Union member states (Moreno, 2012).

Additionally, it is hard to find a European country which has only one subnational level of government; i.e. where there is only one level of local self-government below the central level of government. More precisely, among EU member states - with the exception of Lithuania - there is below the central level usually at least one more form of regional selfgovernment or more than one level of local self-government, and in a significant number of states there are both. Further on, in the majority of European countries, local government is organised in more than one tier. Besides Serbia, there is a single-level local government in Montenegro, Iceland, Switzerland, Austria, and Turkey, and among these only Montenegro and Iceland do not have a regional level of government (CEMR, 2012). Where there is a multilevel local government, the first tier is usually composed of municipalities and the second of towns, counties, districts

16 Council of Europe Reference Framework for Regional Democracy, MCL16 (2009) 11,https:/wcd.coe.int/ViewDoc.jsp?Ref=MCL16\%282009\%2911\&Language=lanEnglish $\&$ Ver $=$ original $\&$ Site $=$ DG1-CDLR $\&$ BackColorInternet $=$ B9BDEE $\&$ BackColorIntranet $=$ FFCD4F\&BackColorLogged=FFC679 
or similar units. The third level, if there is one, usually appears as forms of regional self-government. The rule is that capital cities also have special status, so the capital often simultaneously has the status of a town and a regional authority (e.g. Oslo, Vienna, or Zagreb).

Also, a significant number of states differentiate between certain types of local government units (the polytype model), according them different competences and organisation, either by law (e.g. depending on the size of population or type of settlement) or by leaving it up to the local communities themselves to select the suitable organisation model. The most frequent differentiation is the one between rural and urban communities. Some other feaures of local government systems of other European jurisdicitions which were taken into account include: the existence of a regional level of government and/or regional self-government; the average size of local government units (in terms of territory and population); differentiation between competence type (original and delegated, but also obligatory and/or facultative competences); local electoral systems; and central and regional oversight of local government.

Since these aspects of comparative analysis are already well known in legal and political theory, this paper does not elaborate further in this regard. Instead, turning to a somewhat more elaborate presentation of Serbian local government history, the authors believe that some of its aspects can be fruitful ground for designing future solutions.

Over the period of two centuries, as long as the legislative development of local self-government in Serbia has persisted, there has been a constant struggle between supporters of centralisation and decentralisation (Svirčević, 2011; Milosavljević, 2015). The outcomes of that struggle varied from period to period, but local authorities were more often under strong state control than they were independent. Three main tendencies in the development of Serbian local self-government can be discerned: a tendency to enlarge municipalities, a tendency towards uniformity (the monotype model), and a tendency towards a single-level local government.

A system of small municipalities was maintained in Serbia throughout the $19^{\text {th }}$ century and the first half of the $20^{\text {th }}$ century, with the exception of municipalities established in bigger urban settlements. Even then, there were efforts to enlarge municipalities to certain extent, but never to make them too large. At the beginning of the socialist period, there was also a predominance of small municipalities, but a determined path towards their enlargement started soon. Such steps were justified by the neces- 
sity to create a more significant local government level; i.e. the intention for municipalities to become stronger and competent to overtake a wider range of self-government and administrative state functions (especially the latter). The process of municipality enlargement concluded during the 1960s, so their number has only slightly changed since then.

In the first (1839) Serbian law on municipalities there were no criteria for municipality size. The 1866 law stipulated that "every borough, town or village shall have its own municipality, either for itself, or together with other villages", while a municipality could not have fewer than 200 tax heads (i.e. taxpayers). Some twenty years later (in 1884) there was a demand that a municipality have "at least 500 tax heads", but only five years later (in 1889) the old criterion of 200 tax heads was restored. During the Kingdom of Yugoslavia, the 1933 law required municipalities to have at least 3,000 inhabitants (except when "terrain conditions and other entirely justifiable reasons" demand that there should be a municipality with fewer inhabitants). After the Second World War the process of enlargement accelerated quickly: the number of municipalities in Serbia in 1952 stood at 2,206, in 1955 it had dropped to 737 and finally to 186 in 1966/7. It has not changed significantly since then.

Differentiation between several types of local government units within the same level was a feature of the Serbian system up until 1955. That year marks a transition from a polytype to a monotype organisation, which has subsequently never been departed from, except only partially in the case of towns. While it existed, differentiation was based on the type of settlement and was reflected in: (1) the scope and type of tasks in original and delegated competence, and/or (2) the organisation of self-government bodies.

The 1839 law had already recognised a differentiation of three types ("three classes") of municipalities: the first included only Belgrade, the second districts and other boroughs, and the third villages. The specificity of Belgrade was recognised in 1841, but only as a separate police and administrative authority (the Administration of the Belgrade Borough). Belgrade was later equalised in status with a district as a state administrative authority, and in the sense of self-government it was equal to a municipality, with a specific organisation of bodies. The differences between rural and urban municipalities were maintained later as well, and were primarily apparent in the composition of municipal bodies and to some extent in their competences. Differentiation was most complete during the first Yugoslav state (1918-1941), with the 1921 Constitution envisaging two 
types of municipalities - rural and urban, later regulated by two separate laws (from 1933 and 1934). Urban municipalities (i.e. towns) had a much wider circle of delegated competences, while their self-governing competences were not significantly widened. There were also some differences in the internal organisation of urban and rural municipalities. ${ }^{17}$

After World War II the polytype system was only maintained for a decade, in very complex form. During that time there was "a large number of formally, organisationally and legally fixed forms of people's boards", especially in towns (Pusić, 1985: 119). In 1955 rural and urban municipalities were equalised. The constitutional system introduced in 1963 envisaged the possibility of establishing more municipalities on the territory of large towns, and this was applied in the case of Belgrade. In that way, a town divided into municipalities was composed of two types of local self-government units: the town as the primary unit, and town municipalities as secondary or derived units. However, this did not grant wider competences to the town - only competences generally established for municipalities could be divided between the town and town municipalities. The same model was maintained under the 1974 Constitution, with a possibility of establishing so-called town communities of municipalities (gradske zajednice opstina), which was not applied in Serbia. The 1990 Serbian Constitution enabled some municipalities to be defined as towns by law, with an obligation to form two or more town municipalities. Until 2007 this existed in Belgrade and four other biggest towns. With the 2006 Constitution town municipalities lost the status of local government units.

Two local government levels (municipality - opština and county - srez) existed until 1967. Only seven years later (in 1974) there was an attempt to compensate for the second level with the so-called communities of municipalities (zajednica opština), which were abolished in 1991. Since then, there has been a single-level system with municipalities and towns as ba-

17 On the whole territory of what was then the Kingdom of Yugoslavia, the status of towns was granted to: Bakar, Banja Luka, Bela Crkva, Beograd, Bihać, Bitolj, Bjelovar, Valjevo, Varaždin, Velika Kikinda, Veliki Bečkerek, Vinkovci, Virovitica, Vranje, Vršac, Vukovar, Dubrovnik, Zagreb, Zaječar, Jagodina, Karlovac, Koprivnica, Kotor, Kragujevac, Križevci, Kruševac, Kumanovo, Leskovac, Livno, Ljubljana, Maribor, Mostar, Niš, Nova Gradiška, Novi Sad, Osijek, Pančevo, Petrinja, Peć, Pirot, Podgorica, Požarevac, Prizren, Priština, Ptuj, Ruma, Sarajevo, Senta, Senj, Sisak, Skoplje, Smederevo, Sombor, Split, Sremska Mitrovica, Sremski Karlovci, Stara Kanjiža, Stari grad na Hvaru, Subotica, Sušak, Tetovo, Travnik, Tuzla, Užice, Hvar, Herceg Novi, Celje, Cetinje, Čakovec, Čačak, Šabac, and Šibenik. These towns are now spread over the territories of six separate states descending from the former SFR of Yugoslavia, and some no longer exist. 
sic and single units of local self-government. A single-level system thus existed in Serbia only between 1967 and 1974, and then again from 1991 until today. A third local government level in the form of districts (okrug or oblast) disappeared from time to time, but was nevertheless maintained up until the beginning of the 1950s, when it finally vanished. At one point during the Kingdom of Yugoslavia, there were as many as four levels of territorial units (district and duchy, district, county, and municipality - oblast and banovina, okrug, srez, and opština), two of which were self-government units, one had weak self-government elements, and one had no self-government elements. Besides, village self-government also existed for a period of time (i.e. before the creation of municipalities). It will appear once more, after the Second World War, for a short while, as the primary level of local self-government, in order to evolve into neighbourhood units (mesne zajednice), which, as previously said, do not have the character of local self-government units.

\section{Two Proposed Decentralisation Models}

\subsection{Model 1: Possible Adjustments Within the Current Constitutional Framework}

The first of the two designed models represents a collection of proposals for the advancement of decentralisation within the current constitutional framework. Basically, these are suggestions aimed at eliminating observed deficiencies in the way the local self-government system functions (for the most part presented in Chapter 2), and at the same time aimed at further decentralisation. The realisation of all proposals is feasible without constitutional amendments.

In terms of territorial organisation, two main proposals can be made. First, separate analyses with economic, spatial, demographic, and other indicators need to be carried out in order to estimate the effect of the possible abolition of extremely small municipalities which show a trend of population decline. On the other hand, some larger municipalities could gain town status, in particular those in administrative districts or developmental regions in which there are currently no towns.

Oddly enough, Serbia does not have a full inventory of tasks in competence of all three levels of government (central, provincial, or local). Such an inventory, when completed, could serve as a basis for drafting a list of 
possible new tasks to be transferred or delegated to local governments. In order to overcome the current linear approach in transferring competences, the state needs to develop a methodology for the assessment of criteria for the transfer or delegation of tasks. Moreover, before any decision on the transfer or delegation of tasks is taken, there should be a consultative process involving local government units. Previous studies have shown that when central authorities pass legislation affecting local governments, the latter are most often not consulted (Damjanović et al., 2011). All laws transferring new tasks should list in their rationale the results of the consultative process and assessments, as well as whether adequate resources have been secured, and if administrative and other capacities for the performance of tasks are available. As analyses so far have shown that this is not regular practice, the laws should always clearly state if tasks are being transferred or delegated.

The existing possibilities of delegating wider competences to towns and the Town of Belgrade should be utilised in a more decisive manner. In addition to that, local governments should be enabled to gain additional facultative and/or conditional competences, which they could undertake if they wished to; i.e. if they fulfilled the conditions set by law. That way, the current excuse of not transferring competences to all local governments on account of a lack of capacities would become pointless. Of course, the law should determine deadlines for the fulfilment of such conditions and the procedure for their assessment. In the same way, some of the tasks that are already in the competence of local government could be re-evaluated and consequently determined according to this principle.

Serbia obviously needs a more solid legal framework for inter-municipal cooperation, including the introduction of possible incentives. Legislation could also introduce obligatory cooperation when it is a condition for the quality performance of tasks and when a municipality is not able to perform certain tasks on its own, as well as encourage public-private partnership arrangements.

Within the scope of management of local government functions, both the local electoral system and legal framework, and the practice of citizen participation are in need of improvement. Legislation should determine a list of issues on which citizens must be consulted. In relation to local government bodies, the local executive should be composed of a unique executive body instead of the existing two, and the local administrative structure should be adapted to local needs and demands for efficiency. It could also be useful to standardise models for the establishment of other local bodies, offices, and organisations. 
Even though they are not local government units, the role of town municipalities could be strengthened, especially those that have the status of suburban municipalities. Similarly, a minimal legal framework significant for the position of town municipalities and neighbourhood units should be secured.

Not all proposals relate to local self-government, since there is a need for improvement even in forms of deconcentrated state administration. In that sense, a larger number of tasks could be deconcentrated to administrative districts (which currently almost exclusively include deconcentrated inspections), and, in particular, administrative districts could be given the authority to oversee the performance of the delegated tasks of local government units. Additionally, there is room to affirm the role of the council of the administrative district as a form of consultation and coordination.

Furthermore, besides territorial decentralisation, Serbian decision-makers could take a closer look into forms of functional and personal decentralisation, in terms of specifying the legal framework for the relations between local government units and local public institutions and public services which they have founded. Also, clarification is needed in disputable relations between state and local bodies in relation to local public institutions and services, and there is room for improvement with regard to delegation of tasks from the competences of local government units and concessions of public services.

When it comes to financial decentralisation, a stable and predictable system of local government financing is necessary. Local governments should gain more responsibilities for collecting their own revenues, but they should also rationalise the expenses of their budgets in the financing of the local public sector.

Finally, when it comes to oversight of local self-government, mechanisms of ex post oversight by state and provincial bodies need to be upgraded. In respect of ex ante oversight, there should be regular control over the regulatory acts of local governments, as well as improvement of financial control over local governments, with the possibility of including forms of ex ante oversight. State and provincial bodies should be obliged to cooperate more fully with local government bodies, provide expert support and engage in preventive action with the aim of a proper and efficient application of the law.

A few additional explanatory notes could be added to the proposals relating to towns. First of all, the model advocates a more determined usage of the constitutional possibility to entrust wider competences to towns, in comparison to municipalities. The same proposal applies to Belgrade, 
which, according to the Constitution, can have wider competences than municipalities and other towns. In the authors' opinion, this proposal is supported not only by the size of towns and their generally solid administrative and other necessary capacities to perform new tasks, but also by the need to take a more significant step towards departing from the strict monotype local government system, and to enable towns to take over greater responsibility for solving their own developmental, communal and other problems. The special position of towns in the local government system would be more fully justified if they were identified as subjects of regional development with a leading role in districts (NUTS 3). On that subject, this proposal advocates that town status should be given to those municipalities which are seats of administrative districts, or centres of developmental districts, and have a population of over 50,000 inhabitants, but do not currently have town status. In addition, it is proposed that new tasks be delegated to towns. Among other administrative tasks, this should especially be considered in relation to inspection oversight in certain fields.

If wider competences were delegated to towns and the Town of Belgrade, it would be justified to transfer a significant number of town competences (in comparison to the present situation) to town municipalities, especially in the case of Belgrade and its suburban municipalities. Even though they currently do not have the status of local government units, it seems reasonable to encourage them to take over greater responsibilities, especially when their problems are atypical or different from those in urban zones. This could apply to town municipalities outside of Belgrade, since they now have far more modest competences than those in Belgrade; naturally, with prior evaluation of their capacities to perform new tasks. In addition, the Law on Local Self-Government (or another, separate, law on towns) could secure at least a minimal legal framework for the status of town municipalities. In the authors' view, the issues which should be regulated include: bodies of town municipalities, oversight over their work, financing, and legal personality. There should be an unequivocal extension of application of all (procedural, financial, and other) legislation applicable to public authority bodies, to town municipalities (since they presently do not have that status, as they only perform public tasks from the competence of towns).

\subsection{Model 2: Designing a More Suitable Model}

The authors are aware that the corrections of the present local government system suggested in the first model are of limited scope. Their in- 
troduction could to some extent further the level of decentralisation and secure a more adequate division of competences between central and local levels of government. However, some of the fundamental weaknesses relating to systemic solutions would still exist and strongly influence the functioning of the system. The nature of these weaknesses is such that they hinder a genuine functional division of competences and realisation of the desired extent of decentralisation. In other words, they prevent the establishment of all necessary preconditions for a decentralised, democratic, and efficient system of performance of public tasks.

In order to overcome these weaknesses, the second model thus deviates from some of the current constitutional solutions, and its possible realisation is conditional upon a prior constitutional revision, followed by adequate legal elaboration. The scope of these deviations is strictly limited to the measure necessary to establish the elements of the projected model. In determining the models, the authors have paid attention to the necessity of incorporating the proposals as much as possible into a wider constitutional framework which defines the position of certain levels of government and relations between these. In similar fashion, the second model determines attitudes towards the realities of existing local government institutions - the projected model is a collection of proposals for their perfection and on no account would it neglect or disregard their present values.

Moreover, the second model is envisaged as a continuation of the previously described first model in the sense that the implementation of the proposals from the first model would create a basis for easier introduction of most of the proposals envisaged by the second one. Therefore these would be two phases of the same process - one of local government reform with the aim of wider decentralisation.

The basic elements of the second model are: (1) the establishment of a polytype structure within the first level of local self-government by introducing distinctions in organisation and competences between municipalities, towns and the Town of Belgrade; and (2) the establishment of a middle level of local government (in the form of districts). Besides these two levels of local government, there would be a possibility of (3) forming an association of two or more districts, on a voluntary basis, as forms of regional self-government.

Municipalities, towns and Town of Belgrade would be first-level (basic) local self-government units, while Belgrade would also have district status. Differences between municipalities and towns would relate to the 
organisation of their bodies, as well as their original and delegated competences. The criterion for the size of municipalities could be raised to 20,000 inhabitants with the possibility of exceptions (smaller municipalities with smaller numbers of inhabitants). By applying this criterion, the total number of municipalities would be reduced by at least a third. In the case of small municipalities which would not be abolished, the law could establish an obligation to form an association of administrative communities with neighbouring municipalities or towns, or an obligation to form most or some joint administrative bodies, offices, institutions, public utility companies, and other organisations.

Besides existing towns, this status could be granted to some bigger municipalities, as well as all municipalities which are currently seats of administrative districts, while the criterion for the size of towns could be lowered to 50,000 inhabitants. Towns with town municipalities would differ from those without, as town municipalities would have the status of secondary (derived) local government units (similar to what was envisaged by the 1990 Serbian Constitution) and perform a portion of the tasks in the competence of towns.

For large towns, e.g. those with more than 150,000 inhabitants, the law could establish a mandatory division into town municipalities. The original competences of towns could be widened to include some additional tasks in the fields of urban and spatial planning, construction, urban infrastructure, transport, and so on. Both municipalities and towns could gain some additional competences in the field of communal police and public safety. When delegating tasks from the competence of the central state or autonomous province, towns should be granted a wider range of tasks than municipalities.

In terms of bodies, towns would have an assembly, an executive body, and a town administration. The town assembly could consist of up to 70 councillors (which would be double the number of deputies in municipal assemblies). The mayor (with a deputy) would be the single executive body and would be assisted by a town council composed of five members, elected by the assembly from experts in certain fields. Some of the more important decisions from the mayor's competence could also be made conditional on a prior opinion of the assembly. A town administration could be organised as several separate administrations, but their number should be limited by legislation.

The introduction of the middle (district) level of local self-government could be realised by transforming the existing administrative districts into 
a district level of local government. The territory of present administrative districts should, in that sense, be re-evaluated, and possibly altered, if specially determined needs arise. Besides the existing 29 administrative districts, district status would also be granted to Belgrade.

As a local government level, the district would also have original and delegated competences. Besides passing their own statute and budget, regulating the organisation of district bodies, and managing district public property, original competences could include some tasks related to the establishment and maintenance of public services of importance for the district, realisation of infrastructure projects, taking care of some social and healthcare services, economic development, cultural institutions, secondary education, environmental protection, population protection and rescue, public order, protection of national minorities, and other tasks. As delegated tasks the district should perform some of the tasks now entrusted to municipalities and towns, with new tasks determined among those which are now performed through deconcentrated units in administrative districts, as well as some other tasks. Municipalities and towns could also delegate or entrust the district level with the performance of some of their original tasks, via contract.

The district could be authorised to conduct oversight over first-level local government units, and its bodies could act as the second instance in administrative procedure, upon appeal against first instance decisions of municipal and town bodies in issues of their competence. Central and provincial authorities would conduct oversight over the work of district bodies.

A district assembly would be the highest authority in the district, composed of deputies indirectly elected from the composition of municipal and town assemblies. By election to the district assembly, the deputies would keep their mandates in local assemblies. The number of deputies of the district assembly should not be too large and the assembly could pass decisions by a majority of all deputies. Some of the more important decisions could be made conditional upon a previous opinion or consent of the municipal and town assemblies. The executive body could be a district council whose members would be elected by the district assembly, upon proposal of municipal and town assemblies. There are, naturally, different possible models of executive bodies that could be taken into consideration. District administration would be under supervision of the district council and assembly, and the assembly would elect its head. Some of the existing municipal bodies could be raised to district level, in the form of joint municipal and town bodies. The district level would also be a logical 
basis for the organisation of some regional public services, such as regional landfills and regional water supply systems.

In order for the district level to come to life, it would be necessary to form a certain mass of district property. In addition, in order to finance them, it would be necessary to secure adequate financial resources in the form of some original revenues, resources for conducting delegated tasks, and grants from a higher level of government. Besides the listed challenges, the introduction of districts would certainly generate new expenses, which could be reduced to a minimum if the costs of municipalities, towns, and higher levels of government - which would be relieved of some tasks that would be performed by the district in future - were somewhat reduced. District administration, or at least its greater part, could consist of the employees who have previously performed the same tasks in municipalities, towns, or at higher levels.

As the existing regions (NUTS 2), except in the case of Belgrade, are too large to realise functional cooperation among local government units, a proposal is to consider the idea of creating possibilities for voluntary association through the functional cooperation of two or more districts. The motives for such associations could be found in the realisation of functions of mutual interest, or big projects of regional importance, or projects exceeding the boundaries of an area larger than a single district. Depending on the nature of mutual interests and projects, such associations could be performed on a temporary basis, or for a limited period determined in advance, or on a long-term basis. In order to realise such cooperation, joint bodies could be established and a coordinative role transferred to them. Existing counties (oblasti) encompassing two or more districts could be used as the territorial framework for the realisation of this regional cooperation. Fields of cooperation and forms of its realisation could be indicated more closely. If such models of cooperation were to prove successful in the coming period, for instance in the next ten years, decision-makers could consider establishing a new level of regional self-government.

On the territory of autonomous provinces, the model of regional self-government could have a different outlook, or it could be evaluated as unnecessary due to current possibilities of autonomous provinces to substitute the need for such a form of regional self-government. However, the competences of autonomous provinces, and the reform of the division of competences between the central and provincial level of government were not the direct subject of the authors' analysis, and a proper discussion of these issues would demand a separate comprehensive analysis which would perceive all the important aspects and offer adequate proposals. 


\section{Conclusions and Further Steps}

Deficiencies of the current local government system in Serbia mainly stem from its very construction. Regardless of great discrepancies in size and capacities of local governments, they all have almost the same competences and an almost identical organisation. However, a historical overview of the development of local self-government in Serbia shows that such a system has only existed for a brief period, viewed from the perspective of two centuries. The authors believe that some of these experiences, primarily those relating to the establishment of more levels and different types of local government units, could perhaps be restored in future models.

Based on their territory and average population, local governments in Serbia are among the biggest in Europe, particularly taking into account its single-level local government system. Local governments have been functioning within the same territorial boundaries for over half a century now, despite great changes in population and great systemic changes to their role and expectations of that role since the 1990s. On that subject, the authors propose possible changes in the number of municipalities and towns to be considered, with a view towards a contribution to a more efficient local government system and a more advanced decentralisation model. Besides the possibilities of further enlargement of municipalities, the introduction of a two-level or a multi-level local government should be considered. In any case, there is an evident need for legislative clarification of the status of town municipalities and neighborhood units.

Local government competences now encompass a wide range of diverse tasks, which is particularly true for delegated tasks. The scope of original competences is determined by constitutional and numerous legislation, mainly in accordance with the monotype principle. Unfortunately, the absence of an inventory of public tasks hinders further credible analysis of issues relating to the transfer of competences to existing and possible future local government units.

Furthermore, the current local government system does not recognise evident differences in the level of development of different local governments, hindering the development of the more developed and overburdening the underdeveloped.

The proposed decentralisation models are primarily oriented towards developing an advanced concept of the local self-government system and the relationship between the central and local level of government.

The ideal model, which could, in the authors' opinion, present proposals for overcoming all, or the majority, of the identified deficiences, would 
include a necessity to amend the Constitution. It envisages the establishment of different types of local government units (municipalities, towns, and the Town of Belgrade), as well as the introduction of an additional level of local government. Finally, it does not advocate the introduction of regions as forms of typical regional self-government, but an option to form voluntary associations of second-level local governments, which could, in time, grow into fully-fledged regional governments.

Since constitutional amendments might be hard to achieve (because most parts of the current Serbian Constitution require a two-thirds parliamentary majority followed by a referendum), the authors have also provided proposals for the improvement of the current system which it would be possible to achieve simply via legislative amendments. These proposals are diverse and cover the totality of legislation concerning territorial organisation and local self-government, including even improvements to the existing forms of administrative deconcentration.

The two models are complementary in the manner that the second model can actually be viewed as a continuation of efforts to be conducted under the first model, with an aim of improving the current local government system.

In order for the models to be properly evaluated and finally defined by relevant decision-makers, a cost-benefit analysis needs to be conducted. This task was planned to be finalised during 2015. Finally, the proposed models should be subject to extensive public and expert discussion. The final decision on future steps will be made by the Government and its Council for Public Administration Reform.

\section{References}

CEMR. (2012). Local and regional government in Europe: Structures and competences. Brussels, Belgium: Council of European Municipalities and Regions.

CEMR. (2013). Decentralisation at crossroads: Territorial reforms in Europe in times of crisis. Brussels, Belgium: Council of European Municipalities and Regions.

Damjanović, D., Jerinić J., \& Pavlović-Križanić, Tatjana (2011). Horizontalna $i$ vertikalna koordinacija u postupku donošenja odluka od značaja za lokalnu samoupravu u Srbiji. Belgrade, Serbia: PALGO centar.

Jerinić, J. (2012). Da li nam je potrebna nova teritorijalna organizacija? Agenda, 1, 3-8.

Milosavljević, B. (2009). Sistem lokalne samouprave u Srbiji (Rev. 2nd ed.). Belgrade, Serbia: Stalna konferencija gradova i opština. 
Milosavljević, B. (2012a). Reforma lokalne samouprave u Srbiji. Hrvatska i komparativna javna uprava, 12(2), 749-768.

Milosavljević, B. (2012b). Ustavnopravni koncept teritorijalne autonomije u Srbiji. Pravni život, 558(12), 835-848.

Milosavljević, B., \& Jerinić J. (2012). Nadležnosti jedinica lokalne samouprave u Srbiji: analiza pravnog okvira. Beograd: Program podrške opštinama IPA 2007 Dobra uprava, planiranje i pružanje usluga: Dosije studio

Milosavljević, B., Jerinić J., \& Koetz A. (2012). Modeli organizacione strukture i sistema upravljanja u opštinskoj $i$ gradskoj upravi. Beograd: Program podrške opštinama IPA 2007 Dobra uprava, planiranje i pružanje usluga: Dosije studio

Milosavljević, B., Jerinić J., \& Damjanović D. (2014). Decentralizacija i primena supsidijarnosti u Evropi i Srbiji. Beograd: Ministarstvo državne uprave i lokalne samouprave

Milosavljević, B., \& Nikolić N. (2014). Građani za reformu inspekcija. Beograd: Fondacija Centar za demokratiju

Milosavljević, B. (2015). Dva veka lokalne samouprave u Srbiji: razvoj zakonodavstva (1804-2014). Belgrade, Serbia: Stalna konferencija gradova i opština.

Mojsilović, M. et al. (2011). Neposredno učešće građana u upravljanju lokalnom zajednicom: Problemi, izazovi i prepreke za unapređenje procesa. Belgrade, Serbia: OSCE Mission to Serbia

Moreno, A. M. (2012). Local Government in the Member States of the European Union: A Comparative Legal Perspective, Madrid, Spain: Instituto Nacional de Administración Pública (INAP).

OECD-Sigma. (2013). Serbia Priorities Report 2013. doi: 10.1787/5jz2rql40pbs-en

Pavlović-Križanić, T. (2010). Međuopštinska saradnja u Srbiji: Mogućnosti i izazovi. Belgrade, Serbia: Stalna konferencija gradova i opština.

Petovar, K. (2007). O kriterijumima definicije grada. In D. Milenković \& D. Damjanović (Eds.), U susret novom statusu gradova u Srbiji: Realnost $i$ potrebe (pp. 83-93). Belgrade, Serbia: PALGO centar.

Pusić, E. (1985). Upravni sistemi, II. Zagreb, Croatia: Grafički zavod Hrvatske i Pravni fakultet u Zagrebu.

Stevanović, R. (2004). Gradska naselja Republike Srbije u popisima stanovništva od 1948. do 2002. godine. Stanovništvo, 2004 (1-4), 109-126.

Stojkov, B. (2007). Status grada, decentralizacija i policentričnost Srbije. In D. Milenković \& D. Damjanović (Eds.), U susret novom statusu gradova u Srbiji: Realnost $i$ potrebe (pp. 11-24). Belgrade, Serbia: PALGO centar.

Svirčević, M. (2011). Lokalna uprava i razvoj moderne srpske države: Od knežinske do opštinske samouprave. Belgrade, Serbia: Balkanološki institut Srpske akademije nauka i umetnosti)

Vasiljević, D. (2008). Novi zakonski okvir za lokalnu samoupravu u Srbiji: Lokalna samouprava u Srbiji. In Z. Zlokapa \& D. Damjanović (Eds.), Modeli organizacije lokalne samouprave: Slovenija, Hrvatska, Bosna i Hercegovina, Makedonija i Srbija (pp. 182-227), Belgrade, Serbia: PALGO centar. 
Vasiljević, D. (2012). Lokalni ekonomski razvoj: Zašto su jedne opštine dobitnici, a druge gubitnici tranzicije. Belgrade, Serbia: PALGO centar.

Vukelić, Z. (Ed.) (2006). Direct participation of citizens in local public life. Belgrade, Serbia: Stalna konferencija gradova i opština.

Vuković, Đ. (2015). Zašto menjati izborni sistem? Polis, 9, 24-29.

\section{Legal sources}

Law on territorial organisation of the Republic of Serbia, OG 129/07

Law on the capital, OGRS 129/07

Law on regional development, OGRS 51/09, 30/10

Law on local elections, OGRS 129/07, 34/2010, 54/2011

Law on local self-government, OGRS 129/07, 83/2014

Law on local government financing, OGRS 62/06, 47/11, 93/12

Public Administration Reform Strategy in the Republic of Serbia, OGRS 9/14, $42 / 14$ 


\title{
STATUS OF SERBIAN TOWNS IN THE LIGHT OF RECENT EFFORTS TOWARDS A NATIONAL DECENTRALISATION STRATEGY
}

\begin{abstract}
Summary
u Strategiji reforme javne uprave u Republici Srbiji koja je usvojena početkom 2014. godine decentralizacija je identifikovana kao jedan od ključnib prioriteta. U tom smuslu, Vlada Srbije je u proteklom periodu preduzela odredene korake ka pripremi nacionalne strategije decentralizacije. Srbija trenutno ima jednostepen $i$ gotovo u potpunosti monotipski sistem lokalne samouprave u kom gradovi imaju istu strukturu organa i skoro identične nadležnosti kao opštine, sa minimalnim izuzecima u slučaju grada Beograda, kao glavnog grada. U svetlu tekuće debate o decentralizaciji uopšte $i$, konkretnije, o reformi sistema lokalne samouprave, autori analiziraju neke od važnijih pitanja koja se javljaju u okviru te debate, posebno ona koja se odnose na status gradova uopšte, kao $i$ statusa glavnog grada, $i$ daju predloge za moguću reformu u tom pogledu. Neka od tib pitanja uključuju: mogućnosti za proširenje nadležnosti gradova, a samim tim $i$ kreiranje osnova za politipski sistem lokalne samouprave, organizaciju organa grada, posebno izvršnib organa, kao $i$ najpogodniji način izbora gradonačelnika. Štaviše, autori istražuju mogućnosti za uspostavljanje drugog nivoa lokalne samouprave $i$ položaj gradova u takvom sistemu. Predstavljena analiza zasnovana je na situacionoj analizi sadašnjeg sistema, odabranim uporednim primerima, kao $i$ analizi istorijskog razvoja sistema lokalne samouprave u Srbiji u toku protekle dve decenije. Konačno, navedena pitanja analizirana su iz perspektive sadašnjeg ustavnog okvira, odnosno neophodnosti da se on izmeni sa ciljem definisanja optimalnog modela decentralizacije.

Keywords: decentralisation, strategy, local self-government, local government, town, mayor, Serbia




\title{
STATUS SRPSKIH GRADOVA U SVJETLU PRIPREME NACIONALNE STRATEGIJE DECENTRALIZACIJE
}

\begin{abstract}
Sažetak
Strategija reforme javne uprave u Republici Srbiji, usvojena početkom 2014. godine, prepoznala je decentralizaciju kao jedan od ključnib prioriteta. Vlada Republike Srbije poduzela je odredene korake u smislu pripreme nacionalne strategije decentralizacije. Srbija trenutno ima jednostupanjski $i$ gotovo potpuno monotipski ustroj lokalne samouprave u kojem gradovi imaju istu organizaciju tijela $i$ gotovo identične nadležnosti općinama. Minimalne razlike prisutne su jedino u slučaju grada Beograda kao glavnog grada. U svjetlu trenutne rasprave o decentralizaciji te o reformi sustava lokalne samouprave, u radu se analiziraju neka od važnijib pitanja koja se javljaju u okviru te rasprave, posebice ona koja se odnose na status gradova općenito, kao $i$ na status glavnog grada, te se nude prijedlozi mogućib reformi. Neka od tib pitanja uključuju: mogućnosti proširenja nadležnosti gradova, a samim tim i stvaranje osnove za politipski ustroj lokalne samouprave, organizaciju gradskib tijela, posebice izvršnih, kao i najpogodniji način izbora gradonačelnika. Štoviše, u radu se istražuju mogućnosti uvođenja druge razine lokalne samouprave $i$ položaj gradova $u$ takvom ustroju. Predstavljena se analiza temelji na situacijskoj analizi sadašnjeg sustava, odabranim usporednim primjerima, te analizi razvoja ustroja lokalne samouprave u Srbiji tijekom posljednja dva desetljeća. Konačno, navedena se pitanja analiziraju iz perspektive sadašnjeg ustavnog okvira, te nužnosti njegove promjene u svrbu pronalaska optimalnog modela decentralizacije.

Ključne riječi: decentralizacija, strategija, lokalna samouprava, lokalna vlast, grad, gradonačelnik, Srbija
\end{abstract}

